\title{
Definition, Categorization, and Environmental Risk Assessment of Biopharmaceuticals
}

Rasmussen, Anne Sofie Bruun; Hammou, Aja; Poulsen, Trine Fyhn; Laursen, Marie Christine; Hansen, Steffen Foss

Published in:

Science of the Total Environment

Link to article, DOI:

10.1016/j.scitotenv.2021.147884

Publication date:

2021

Document Version

Publisher's PDF, also known as Version of record

Link back to DTU Orbit

Citation $(A P A)$ :

Rasmussen, A. S. B., Hammou, A., Poulsen, T. F., Laursen, M. C., \& Hansen, S. F. (2021). Definition, Categorization, and Environmental Risk Assessment of Biopharmaceuticals. Science of the Total Environment, 789, [147884]. https://doi.org/10.1016/j.scitotenv.2021.147884

\section{General rights}

Copyright and moral rights for the publications made accessible in the public portal are retained by the authors and/or other copyright owners and it is a condition of accessing publications that users recognise and abide by the legal requirements associated with these rights.

- Users may download and print one copy of any publication from the public portal for the purpose of private study or research.

- You may not further distribute the material or use it for any profit-making activity or commercial gain

- You may freely distribute the URL identifying the publication in the public portal 


\title{
Definition, categorization, and environmental risk assessment of biopharmaceuticals is
}

\author{
Anne Sofie Bruun Rasmussen ${ }^{1}$, Aja Hammou ${ }^{1}$, Trine Fyhn Poulsen ${ }^{1}$, \\ Marie Christine Laursen, Steffen Foss Hansen * \\ Department of Environmental Engineering, Technical University of Denmark, Kgs. Lyngby, Denmark
}

\section{H I G H L I G H T S}

- A clear definition of biopharmaceuticals is needed and is proposed.

- Biopharmaceuticals have been categorized according to biological structure.

- Relevant research regarding environmental risk assessment of biopharmaceuticals are scarce.

- We recommend that environmental risk assessment is not based entirely on the natural origin of a product.

- Categorical exclusion of biopharmaceuticals in EU guidelines for environmental risk assessment is not advantageous.

\section{A R T I C L E I N F O}

\section{Article history:}

Received 1 February 2021

Received in revised form 12 April 2021

Accepted 13 May 2021

Available online 19 May 2021

Editor: Kevin V Thomas

\section{Keywords:}

Biopharmaceuticals

Definition

Categorization

Environmental risk assessment

European medicines agency

Review

\section{G R A P H I C A L A B S T R A C T}

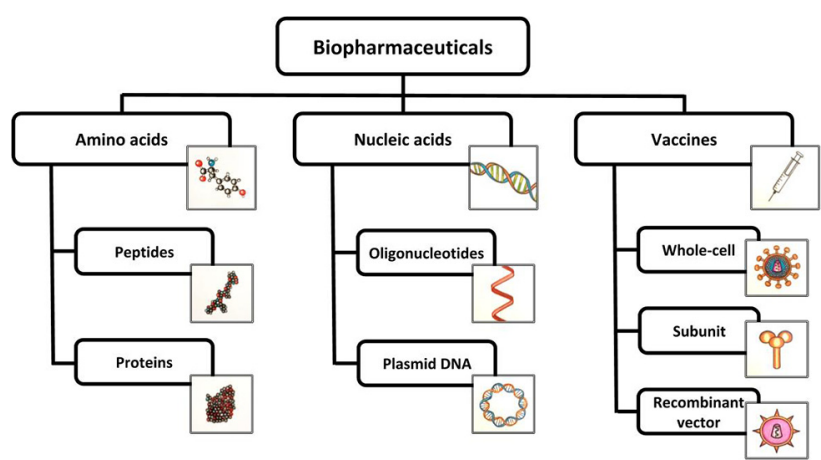

\begin{abstract}
A B S T R A C T
Biopharmaceuticals are associated with the revolutionary treatment of various diseases, and according to the European Medicines Agency, biopharmaceuticals derived from biological sources are perceived to not cause significant environmental risk. However, there is currently no broadly recognized definition or categorization of biopharmaceuticals despite the fact that improved technology has made it possible to modify them to obtain more efficient medicines, thereby raising questions about their biological origins and risks. The aim of this paper, based on a literature review, is to derive a clear definition of biopharmaceuticals and evaluate the European Union's regulation and environmental risk assessment (ERA) procedures for them. Nine different definitions were identified, and it is evident that the term "biopharmaceuticals" is used ambiguously. We therefore recommend that biopharmaceuticals are defined as complex molecules derived from a biological source, with the purpose to diagnose, prevent, treat, or cure diseases or conditions of human beings. Furthermore, we recommend that biopharmaceuticals should be categorized according to their biological structure: 1) amino acids, 2) nucleic acids, and 3) vaccines. Only 11 studies were identified as being relevant to ERA, and we lack useful data for hazard identification. More research is needed to examine the ecotoxicity, fate, and stability of most biopharmaceuticals -and categorical regulatory exclusion seems unfavorable in this regard.
\end{abstract}

(c) 2021 The Authors. Published by Elsevier B.V. This is an open access article under the CC BY license (http:// creativecommons.org/licenses/by/4.0/).

\footnotetext{
This research did not receive any specific grant from funding agencies in the public, commercial, or not-for-profit sectors.

* Corresponding author.

E-mail address: sfha@env.dtu.dk (S.F. Hansen).

1 The authors contributed equally.
} 


\section{Contents}

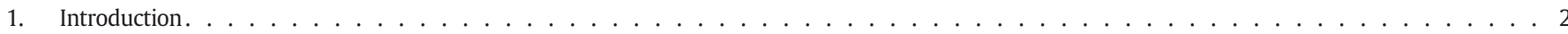

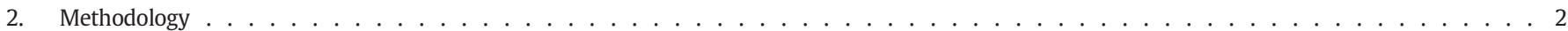

3. Results and discussion . . . . . . . . . . . . . . . . . . . . . . . . . . . . . . . . . . . . . . . . .

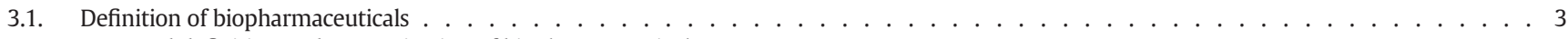

3.2. Proposed definition and categorization of biopharmaceuticals . . . . . . . . . . . . . . . . . . . . . . . . . . . . . . . . 5

3.3. Environmental risk assessment of biopharmaceuticals . . . . . . . . . . . . . . . . . . . . . 6

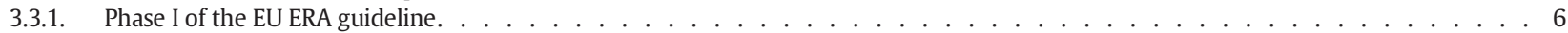

3.3.2. Phase II of the EU ERA guideline $\ldots \ldots \ldots \ldots \ldots$

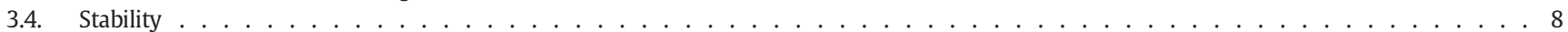

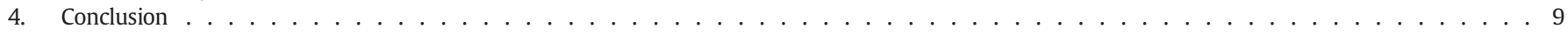

Declaration of competing interest. . . . . . . . . . . . . . . . . . . . . . . . . . . . . . .

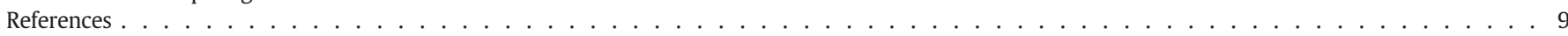

\section{Introduction}

Biopharmaceuticals are associated with the revolutionary treatment of diseases, including cancer, heart diseases, infections, arthritis, and multiple sclerosis (BIO, 2007). In 2016, approximately 200 biopharmaceuticals had been introduced to the market, representing about $10 \%$ of all prescription medications. As of 2018, a total of 374 biopharmaceuticals had been approved by the US and the EU to treat various diseases (Parker and $\mathrm{Li}$, 2021), and by 2020, biopharmaceuticals were anticipated to make up more than 50\% of the top 100 drug sales (Foldvari et al., 2016; Lybecker, 2016), albeit, to the best of our knowledge, actual information on this last point is not currently available. Most biopharmaceuticals are now produced by recombinant DNA technology (Conner et al., 2014), whereby the gene of interest is transferred into a host organism, thus making the host produce the biopharmaceutical.

Compared to small molecule (SM) drugs, biopharmaceuticals are considered less hazardous by Committee for Medicinal Products for Human Use of the European Medicines Agency, as they are derived from a biological source (CHMP, 2006). SM drugs have a well-defined structure consisting of single molecules, and they can therefore be characterized easily. In contrast, biopharmaceuticals can be 200-1000 times the size of SM drugs (Lybecker, 2016), and given their complexity, the manufacturing process is similarly complex and sensitive. Small changes in factors such as temperature or other growth conditions can influence biopharmaceuticals' characteristics, and these variations, such as the substitution of a single amino acid or the alteration of a pattern of sugar residues, can further alter overall biological activity (BIO, 2007).

Most biopharmaceuticals are designed to imitate a native human biological mechanism (Tang et al., 2004), and the investigation of these products can thus be challenging and often present toxicity issues distinct from the screening of chemical compounds. Toxicology screening of chemically synthesized drugs typically focuses on the identification of toxic metabolites, which can be produced from a drug that has been ingested. In contrast, biopharmaceuticals are made to imitate endogenous pathways, which are not fully understood but can nevertheless alter the result of toxicology screening (BIO, 2007).

According to the European Union (EU), marketing authorization applications (MAAs) for all new pharmaceuticals must be accompanied by an environmental risk assessment (ERA) (CHMP, 2006). However, the guideline, which came into force in 2006, states that biopharmaceuticals are unlikely to course a significant risk to the environment, due to the nature of the products, and therefore the evaluation may consist of a simple justification for not submitting ERA studies (CHMP, 2006). Kümmerer (2009) has argued that environmental relevance regarding biopharmaceuticals is not the focus of or relevant to general environmental research and risk management, as they are closely related to natural products, and thus they are expected to be quickly biodegraded or inactivated in the environment. However, it is well established that biopharmaceuticals can be modified, thereby raising questions about the biological nature of these pharmaceuticals, which in turn gives rise to questions about whether they are currently being properly riskassessed and regulated from an environmental point of view.

In this paper, we use the term "biopharmaceuticals" as a denominator for "biologics," "biologicals," "biological product," "biological drug," "biological medicine," "biological medicinal product," etc. However, many different terms are often used interchangeably in the literature, and there is currently no broadly recognized or clear definition (NHS Pharmaceutical Research and Development Working Group, 2017). This categorization, however, is fundamental for the effective functioning of a given regulation, as it establishes the subject matter and scope of what is to be regulated and clarifies whether and which biopharmaceuticals might fall under the scope of the regulation, as well as who has to comply with different requirements therein. If definitions are unclear, there is a possibility that a given pharmaceutical will not undergo the relevant and intended safety assessments (Bowman et al., 2010).

The aim of this paper is two-fold. First, we aim to review contemporary knowledge regarding biopharmaceuticals and investigate whether it is possible to obtain a clear definition and categorization in this regard. Second, we aim to investigate whether existing EU regulation and ERA guidelines on the human use of pharmaceuticals are sufficient for handling biopharmaceuticals. Only active ingredients that are part of the final product are considered within the scope of our analysis. Biosimilars and genetically-modified active ingredients are also excluded from our analysis, as they are subjected to special regulatory and ERA procedures in the EU.

\section{Methodology}

In order to identify the relevant literature, we used Web of Science (WoS) database website and reviewed research published between January 1900 and July 2019. For every biopharmaceutical synonym identified throughout the study, we refined each result with the keywords definition, classification, categorization, environment, risk assessment, and environmental risk assessment. Since the numbers of hits vary substantially, an upper limit of 5000 with respect to the overall number of hits was set.

Studies identified initially as relevant were evaluated for quality, using critical thinking with regard to whether the hypotheses tested were clearly stated, the methodology was well-described, the findings were presented in a transparent and reproducible manner, and, finally, that the derived conclusions seemed plausible when taking the limitations of the applied methodology and study delimitations into consideration.

All identified definitions were analyzed with respect to the following categories: Source reliability, year of publication, and whether the biological derivation, composition, and purpose were included.

In order to examine the pros and cons of the ERA of biopharmaceuticals, EU legislation on pharmaceuticals marketing was evaluated with regard to purpose, relevance, and ERA guidance. Eur-lex was used to identify available and relevant legislation in force, using "marketing," "pharmaceuticals," and "environmental" as keywords. Current EU 
ERA guidelines were scrutinized along with a draft version of the EU guideline on the ERA of medicinal products for human use. Based on this literature survey, studies concerning biopharmaceutical testing, related to the investigation of environmental risk, were evaluated with regard to the overall relevance of the obligatory ERA tests specified in the EU guideline and draft guidance.

\section{Results and discussion}

Depending on the applied keywords, the available literature varied substantially, from 0 up to approximately one million papers (see Fig. 1).

The use of terms "Biologics," "Biologicals," "Biopharmaceutical*," and "Biological product" resulted in more than 5000 hits. When the search was specified with a given keyword, WoS gave a lower number of available works for all terms, apart from "Biologicals," because the term can also refer to biological effects or targets and anything biological in origin. When the search "Biopharmaceutical" was refined by adding the words "classification," "definition," or "categorization," only 512, 69, and six hits were obtained, respectively. When refining the result with the words "environment," "risk assessment," or "environmental risk assessment," 299, 84, and one hit were obtained, respectively.

Although it could appear that there is plenty of literature available, the majority of the identified papers-after closer scrutiny-had to be excluded as irrelevant. For instance, often the word, "environment" turned out to be used to describe the surroundings in which the biopharmaceuticals appear, for example in the human body. Overall, we were only able to identify 11 published articles from 1969 to 2018 that were relevant to the environmental risk assessment of biopharmaceuticals. Multiple legal acts were identified, all based upon the conditions laid out in EU Directive 2001/83/EC concerning the human use of pharmaceuticals and Regulation (EC) No 726/2004 on the authorization and supervision of medicinal products for human and veterinary use.

\subsection{Definition of biopharmaceuticals}

Ultimately, nine different definitions of biopharmaceuticals were identified (see Table 1), and although they are somewhat ambiguous, a general trend seems to be that biopharmaceuticals are defined by the way they are manufactured (BIO, 2007; Lybecker, 2016; Walsh, 2002).

The most detailed definition is provided by the Public Health Service Act (2011) (see Table 1). This Act itemizes the pharmaceuticals that can compose a biopharmaceutical and underlines that any chemically synthesized polypeptide cannot be considered a biopharmaceutical. However, biological derivation is not directly specified, which results in a less comprehensive definition. Furthermore, uncertainties are created by formulating products as being 'analogous', as this can refer to a large number of products. Overall, the Public Health Service Act (2011) definition has many qualities, in that the source is reliable, the year of publication is recent, and it complies in terms of composition and purpose.

Although the Public Health Service Act (2011) definition became effective in 2011, it is not the first time that this Act has defined biopharmaceuticals, as many of the identified definitions can be found in a previous publication, namely BIO (2007), which defined them as "generally large, complex molecules produced using living organisms." This definition is a significantly shorter and less detailed version (see Table 1 ), and consequently it is not very specific and covers a broad range of products. On the other hand, a definition that is not as specific might include compounds, which are not necessarily biopharmaceuticals, in which case the purpose of the definition becomes less clear.

The U.S. Food and Drug Administration (FDA) (FDA, 1998; FDA, 2015) also based their definition on the Public Health Service Act (2011) (see Table 1) and defined biopharmaceuticals as "any virus, therapeutic serum, toxin, antitoxin, vaccine, blood, blood component, derivative, allergenic product, or analogous product applicable to the prevention, treatment, or cure of a disease or condition of human beings (section 351 of the Public Health Service Act)." It is notable that proteins at that time were not embodied as a potential component in biopharmaceuticals. As the FDA (2015) definition is taken from the Public Health Service Act (2011), it has the same qualities. Another very specific definition is provided by the European Commission (2014) (see Table 1), which states that proteins that are chemically synthesized are not definitely excluded from being considered a

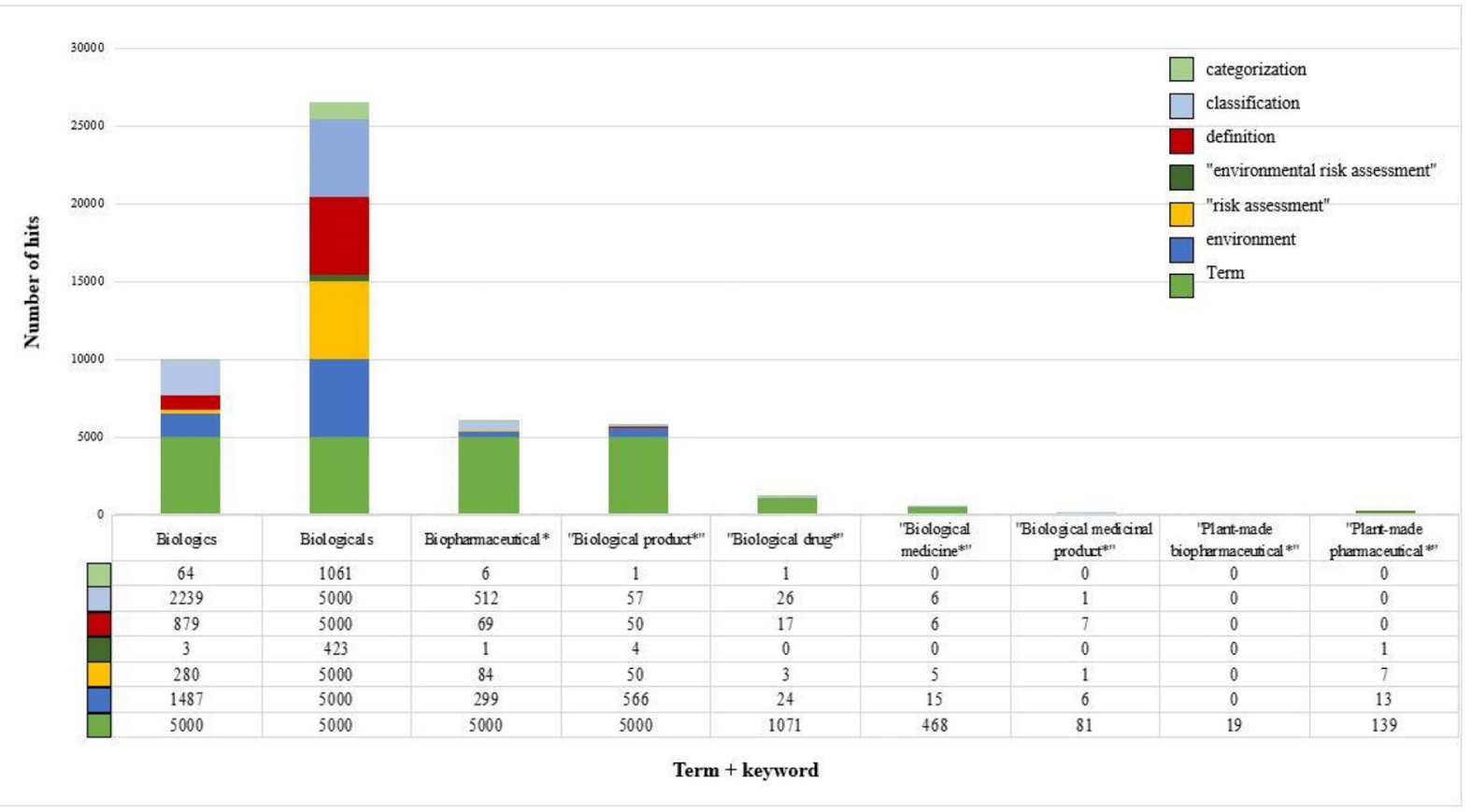

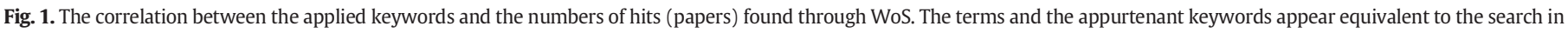

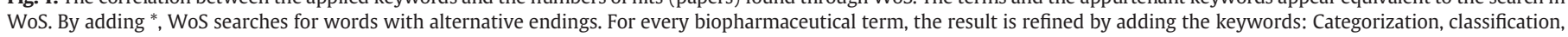
definition, environment, risk assessment, and environmental risk assessment. Citation signs are added so that the keywords are searched for in the correct order. 
Table 1

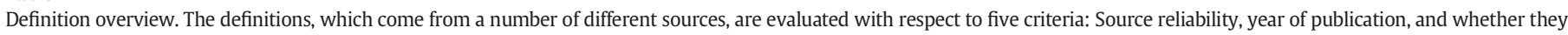
include biological derivation, composition, and purpose.

\begin{tabular}{|c|c|c|}
\hline Source & Definition & Reflections \\
\hline $\begin{array}{l}\text { The Public Health Service Act (42 U.S.C. } \S \\
\text { 262(i)) This updated definition became } \\
\text { effective on January the 7th of } 2011 .\end{array}$ & $\begin{array}{l}\text { The term 'biological product' means a virus, therapeutic serum, } \\
\text { toxin, antitoxin, vaccine, blood, blood component or derivative, } \\
\text { allergenic product, protein (except any chemically synthesized } \\
\text { polypeptide), or analogous product, or arsphenamine or derivative } \\
\text { of arsphenamine (or any other trivalent organic arsenic } \\
\text { compound), applicable to the prevention, treatment, or cure of a } \\
\text { disease or condition of human beings. }\end{array}$ & $\begin{array}{l}\text { The biological derivation is not directly specified, but a detailed } \\
\text { description of substances that can be included to form a } \\
\text { biopharmaceutical is outlined. The formulation 'analogous } \\
\text { product' implies uncertainty. }\end{array}$ \\
\hline Food and Drug Administration (FDA, 1998) & $\begin{array}{l}\text { Any virus, therapeutic serum, toxin, antitoxin, vaccine, blood, blood } \\
\text { component, derivative, allergenic product, or analogous product } \\
\text { applicable to the prevention, treatment, or cure of a disease or } \\
\text { condition of human beings (section } 351 \text { of the Public Health Service } \\
\text { Act). }\end{array}$ & $\begin{array}{l}\text { The FDA has based its definition on an older version from the } \\
\text { Public Health Service Act. }\end{array}$ \\
\hline Food and Drug Administration (FDA, 2015) & $\begin{array}{l}\text { A biological product, as defined in section 351(i) of the Public } \\
\text { Health Service Act, is a virus, therapeutic serum, toxin, antitoxin, } \\
\text { vaccine, blood, blood component or derivative, allergenic product, } \\
\text { protein (except any chemically synthesized polypeptide), or } \\
\text { analogous product, or arsphenamine or derivative of } \\
\text { arsphenamine (or any other trivalent organic arsenic compound), } \\
\text { applicable to the prevention, treatment, or cure of a disease or } \\
\text { condition of human beings. }\end{array}$ & $\begin{array}{l}\text { Identical to the Public Health Service Act definition, it is evident } \\
\text { that the definition has become significantly more detailed since } \\
\text { 1998. The formulation 'analogous product' implies uncertainty. }\end{array}$ \\
\hline BIO (2007) & $\begin{array}{l}\text { Biological products are generally large, complex molecules } \\
\text { produced using living organisms. }\end{array}$ & $\begin{array}{l}\text { Significantly shorter compared to the Public Health Service Act } \\
\text { example. Focuses mainly on biological derivation. }\end{array}$ \\
\hline \multicolumn{3}{|l|}{$\begin{array}{l}\text { Based on the definition from the Public } \\
\text { Health Service Act }\end{array}$} \\
\hline The European Commission (2014) & $\begin{array}{l}\text { Biological medicines (also called 'biopharmaceuticals') are } \\
\text { comprised of proteins such as hormones (growth hormones, } \\
\text { insulins, erythropoietins), enzymes that are naturally produced in } \\
\text { the human body, or monoclonal antibodies, but also blood } \\
\text { products, immunological medicinal products such as sera and } \\
\text { vaccines, allergens, and advanced technology products such as } \\
\text { gene and cell therapy products. Like all medicines, biological } \\
\text { medicines work by interacting with the body to produce a } \\
\text { therapeutic outcome, but the mechanisms by which they do this } \\
\text { may vary from product to product and across indications. }\end{array}$ & $\begin{array}{l}\text { Detailed description of substances that can be included to form } \\
\text { a biopharmaceutical. Can appear confusing, due to its length. }\end{array}$ \\
\hline Lybecker (2016) & $\begin{array}{l}\text { Biopharmaceuticals are defined as 'a large molecule typically } \\
\text { derived from living cells and used in the treatment, diagnosis, or } \\
\text { prevention of disease. Biologic medicines include therapeutic } \\
\text { proteins, DNA vaccines, monoclonal antibodies, and fusion } \\
\text { proteins'. }\end{array}$ & $\begin{array}{l}\text { With respect to biological derivation, the word 'typically' } \\
\text { implies uncertainty and does not exclude chemically } \\
\text { synthesized products. }\end{array}$ \\
\hline Crommelin et al. (2003) & $\begin{array}{l}\text { Biopharmaceuticals are defined as 'pharmaceutical products } \\
\text { consisting of (8lycol)proteins and/or nucleic acids'. }\end{array}$ & $\begin{array}{l}\text { Not very detailed. The biological derivation is left out, and it } \\
\text { describes few components. }\end{array}$ \\
\hline Walsh (2002) & $\begin{array}{l}\text { A protein- or nucleic acid-based pharmaceutical substance used for } \\
\text { therapeutic or in vivo diagnostic purposes, which is produced by } \\
\text { means } \\
\text { other than direct extraction from a native (non-engineered) } \\
\text { biological source. }\end{array}$ & $\begin{array}{l}\text { The biological derivation is left out, and it only specifies protein } \\
\text { and nucleic acids as key components. }\end{array}$ \\
\hline MedicineNet.com (Ogbru, 2019) & $\begin{array}{l}\text { - A biologic drug (biopharmaceuticals) is a product that is } \\
\text { produced from living organisms or contains components of living } \\
\text { organisms. } \\
\text { - Biologic drugs include a wide variety of products derived from } \\
\text { human, animal, or microorganisms by using biotechnology. } \\
\text { - Types of biologic drugs include vaccines, blood, blood } \\
\text { components, cells, allergens, genes, tissues, and recombinant } \\
\text { proteins. } \\
\text { - Biologic products may contain proteins that control the action of } \\
\text { other proteins and cellular processes, genes that control production } \\
\text { of vital proteins, modified human hormones, or cells that produce } \\
\text { substances that suppress or activate components of the immune } \\
\text { system. } \\
\text { - Biologic drugs are sometimes referred to as biologic response } \\
\text { modifiers because they change the manner of operation of natural } \\
\text { biologic intracellular and cellular actions. }\end{array}$ & Quite detailed but can appear confusing, due to its length. \\
\hline
\end{tabular}

biopharmaceutical. This is in contrast to the Public Health Service Act (2011), which points out that for proteins, only products that have not been chemically synthesized can be considered a biopharmaceutical. Another aspect is the length of the definition provided by the European Commission (2014), which due to the details provided can make it confusing.

An example of a definition that is very short in length and stems from the scientific literature is offered by Crommelin et al. (2003): "Biopharmaceuticals are defined as 'pharmaceutical products consisting of (9lycol)proteins and/or nucleic acids'." It is limited to a few sentences only and does not mention anything about the origin of the (9lycol)proteins or nucleic acids (see Table 1). Furthermore, it does not mention any of the other possible biopharmaceuticals or the complexity of the molecules. The definition by Lybecker (2016) is more detailed compared to Crommelin et al. (2003): "Biopharmaceuticals are defined as 'a large molecule typically derived from living cells and used in the treatment, diagnosis, or prevention of disease. Biologic medicines include therapeutic proteins, DNA vaccines, monoclonal antibodies, and fusion proteins'. It 
mentions that the molecules are large and derived from living cells, but the word "typically" precedes "derived," thereby suggesting that the chemically synthesized molecules are not excluded from their definition. Like Crommelin et al. (2003), Lybecker (2016) does not include every biopharmaceutical but only therapeutic proteins, DNA vaccines, monoclonal antibodies, and fusion proteins (see Table 1). This is in contrast to the Public Health Service Act (2011) and European Commission (2014) definitions. Another scientific paper, Walsh (2002), defines biopharmaceuticals as: "A protein- or nucleic acid-based pharmaceutical substance used for therapeutic or in vivo diagnostic purposes, which is produced by means other than direct extraction from a native (nonengineered) biological source." It does not describe biological derivation, and it only specifies protein and nucleic acids as key components.

Lastly, one online definition stemmed from MedicineNet.com and was developed by Ogbru (2019). It is quite detailed, as it includes the origin without including the chemically synthesized molecules. It furthermore mentions several of the possible biopharmaceuticals but uses very generic language when, for instance, it mentions "cells and genes" instead of the specific molecules. This could be due to the purpose of the web page, namely, as a source where a citizen can look up a given definition or explanation and-without biological knowledge-somehow understand it. Due to the details provided in the definition, it becomes quite long, which again can make it confusing.

\subsection{Proposed definition and categorization of biopharmaceuticals}

The definitions offered by the Public Health Service Act (2010), the FDA (2015), and the European Commission (2014) seem to entail most of the qualities we require, i.e. source reliability, year of publication, composition, and purpose. Nonetheless, one general limitation for all of these definitions is their specificity. For instance, they all use examples as part of their definitions, and as a consequence, some products might therefore be excluded.

We find the biological derivation and purpose of biopharmaceuticals to be an important starting point for a comprehensive definition, and therefore we recommend defining biopharmaceuticals as complex molecules derived from a biological source, with the purpose to diagnose, prevent, treat, or cure diseases or conditions of human beings. They can comprise viruses, therapeutic serum, toxins, antitoxins, vaccines, blood, blood components or derivatives, allergenic products, proteins, analogous products, nucleic acid, and trivalent organic arsenic compounds. We do not recommend that these examples are included in the actual definition. Biopharmaceuticals are by definition derived from a biological source; hence, our suggested definition does not include any compounds, which are entirely chemically synthesized. This includes biopharmaceuticals that have been chemically modified after extraction, in order to enhance desired properties such as final product stability. It does not, however, include small molecules purified from biological sources.

The available literature tends to refer to biopharmaceuticals by listing different products but without any clear categorization. Therefore, we propose that they should be categorized according to biological structure and function into three main categories, namely, amino acids, nucleic acids, and vaccines (see Fig. 2).

In our proposed categorization framework, peptides and proteins constitute two different subcategories. Proteins are larger than peptides and have molecular weights ranging from approximately $10 \mathrm{kDa}$ to 200 $\mathrm{kDa}$, or even higher. They can be produced, for instance, by fermentation, using primarily microbes or mammalian cells. Polypeptides, however, consist of 20 to 40 amino acids with molecular weights typically below five kDa (Ho et al., 2010). Furthermore, they can be produced by chemical synthesis, primarily through solid-phase synthesis (Ho et al., 2010), so we believe that it is important to make a distinction between the two amino acid-based subcategories. Similar to amino acidbased biopharmaceuticals, nucleic acids can also be divided into two subcategories, i.e. oligonucleotides and plasmid DNA. As with synthetic peptides, the manufacturing of oligonucleotides is typically closer to that of SM drugs. Oligonucleotides are generally produced by synthesizing chemical DNA or RNA. Plasmid DNA, on the other hand, consists of circular strands of DNA, much larger than oligonucleotides and produced by fermentation, using microbial cells (Ho et al., 2010). The last main biopharmaceuticals category that we propose to include in our categorization framework is vaccines. This category includes a wide range of components but can be divided into three subcategories: Whole-cell vaccines, subunit vaccines, and recombinant vector vaccines. The production of vaccines varies substantially, from the attenuation of live organisms to techniques using molecular biology, where the latter is a similar approach to the one used for SM drugs (Bergquist and

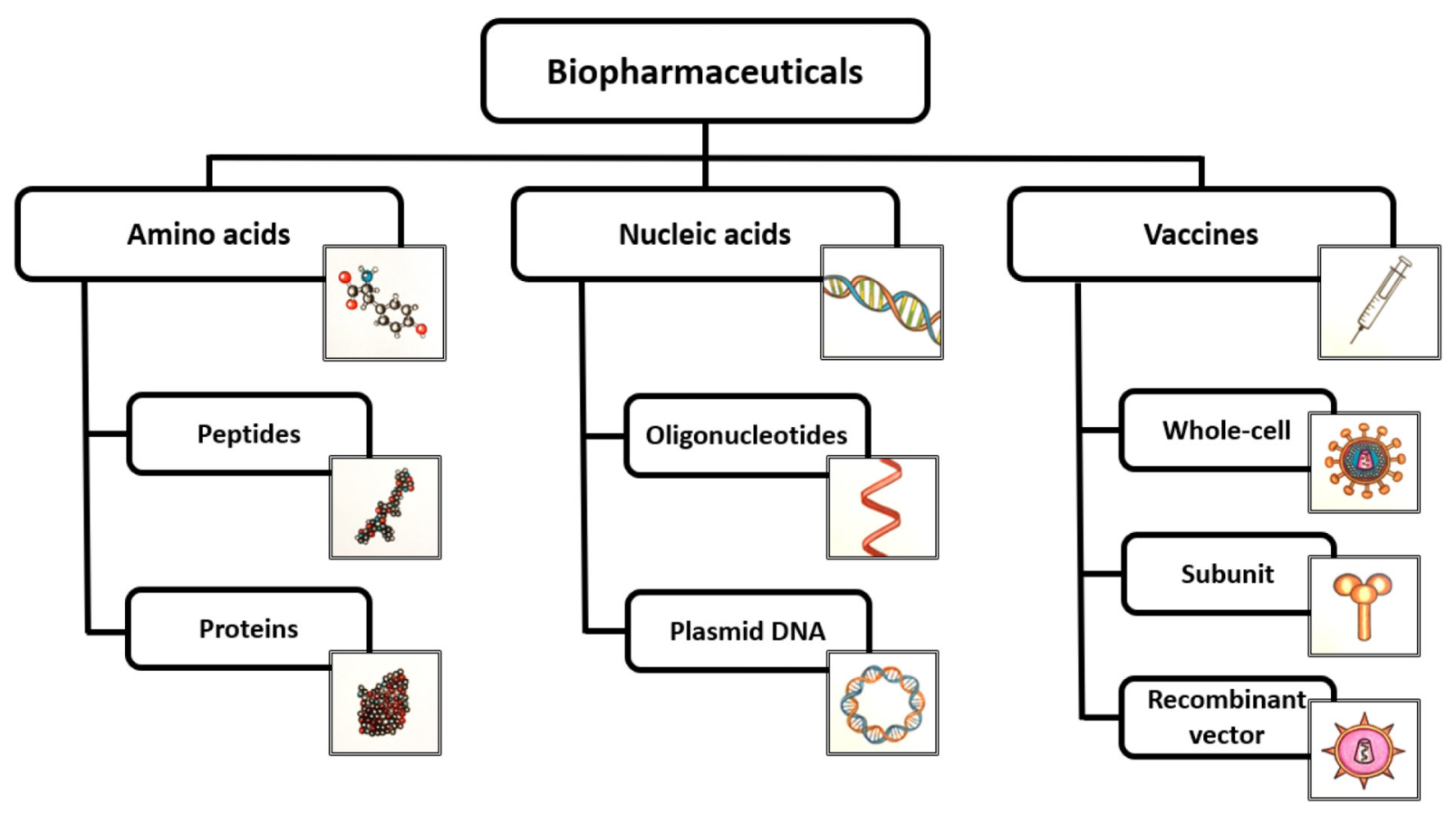

Fig. 2. The categorization of biopharmaceuticals into three main categories, namely, amino acids, nucleic acids, and vaccines. 
Lustigman, 2010). It is important to note that some biopharmaceuticals fall under more than one main category, such as vaccines, which can be comprised of proteins and/or nucleic acids.

A major benefit of the proposed categorization framework is that it enables a distinction between a wide range of pharmaceuticals, which would otherwise be articulated as belonging to the same category. This categorization could subsequently facilitate safety testing and evaluation. According to the definition provided in this paper, biopharmaceuticals are generally defined by the way they are manufactured, and by the fact that they are derived from a biological source. However, from the categorization, it is evident that some of the compounds can be produced via chemical synthesis, which suggests that the categorization of biopharmaceuticals includes categories thataccording to the definition provided-are excluded from being classed as biopharmaceuticals. In order to provide an overview, we have chosen to include all possible categories in the categorization. Even though this is not consistent with the provided definition, we find it important to incorporate pharmaceuticals that can be produced by both chemical synthesis and via the use of a biological origin. Thus, we find that the end-product should be the main focus in any categorization. This categorization is a general overview, and therefore not all biopharmaceuticals provided in the definition are considered.

\subsection{Environmental risk assessment of biopharmaceuticals}

According to EU Directive 2001/83/EC and Regulation (EC) No 726/ 2004 , no medicinal product is to be placed on the market of a member state without the permission of the component authorities of that member state (European Parliament, 2001; European Parliament, 2004). Marketing authorization can be issued through several procedures: Centralized, mutual recognition, decentralized or national (EMA, 2015). To obtain marketing authorization, an MAA must be made and presented to the component authority of the concerned member state. For the centralized procedure, the European Medicines Agency (EMA) is responsible for evaluating MAAs (EMA, 2015). As part of the MAA, an assessment of risk and safety is required, and this includes an ERA concerning the environmental risk arising from the use, storage, and disposal of the medicinal product (European Parliament, 2001). However, the guideline on how to perform an ERA focuses on the environmental risk associated with use, as sewage systems are assumed to be the main route of entry for pharmaceuticals entering the environment (CHMP, 2006; European Commission, 2019).

Through a tiered approach (see Table 2), guidance is provided on how to include an ERA in an MAA (CHMP, 2006). This guideline came

Table 2

The recommended studies for Phase I and Phase II (Tier A and B) in the tiered approach for assessing environmental risk of medical products for human use, according to the current EU guideline (Inspired by CHMP, 2006).

\begin{tabular}{|c|c|c|c|}
\hline Stages & & Test type or parameter & Recommended protocol \\
\hline \multirow[t]{8}{*}{ Phase I } & & Log $\mathrm{K}_{\mathrm{OW}}$ & OECD 107/ OECD 117/ \\
\hline & & PEC & OECD 123 \\
\hline & & & Calculation of action limit \\
\hline & & Adsorption test & OECD 106/ OECD 121 \\
\hline & & Ready biodegradability test & OECD 301 \\
\hline & & Aerobic and anaerobic transformation & OECD 308 \\
\hline & Tier A & Growth inhibition test & OECD 201 \\
\hline & & Reproduction test & OECD 211 \\
\hline \multirow[t]{7}{*}{ Phase II } & & Early life stage toxicity test & OECD 210 \\
\hline & & Respiratory inhibition test & OECD 209 \\
\hline & & $\begin{array}{l}\text { Aerobic and anaerobic } \\
\text { transformation in soil }\end{array}$ & OECD 307 \\
\hline & Tier B & Nitrogen transformation test & OECD 216 \\
\hline & & Growth test & OECD 208 \\
\hline & & Acute toxicity tests & OECD 207 \\
\hline & & Reproduction test & ISO 11267 \\
\hline
\end{tabular}

into force in 2006, and an updated draft guideline was made available to the public in December 2018 (CHMP, 2018). The purpose of both guidelines is to outline and describe the potential environmental risks arising from the use of human medicinal products, in order to ensure that release of both biologically and chemically-originated pharmaceuticals are safe (CHMP, 2006; CHMP, 2018). The EU guideline stresses that the patient's safety is always of the uppermost importance, and in any case, the environmental impact will never lead to a refusal of marketing authorization (CHMP, 2006; CHMP, 2018). The overall requirements on how to perform an ERA did not change significantly with the updated draft; however, the structures of the different components were updated, in order to achieve transparency. For the updated draft, the tests performed in Phase II Tier A are divided into three mandatory sections: Surface water, sediment, and soil, with Organization for Economic Co-operation and Development (OECD) 308 replaced by OECD 225, OECD 218/219, or OECD 233. Furthermore, it is mandatory to incorporate data on physico-chemical properties in Phase II Tier A. In addition, stability testing of non-naturally proteins and peptides is included in Phase I of the updated draft (CHMP, 2018).

According to the EU guideline on ERAs of medicinal products for human use, "medicinal products comprised of naturally occurring substances such as vitamins, electrolytes, amino acids, peptides, proteins, nucleotides, carbohydrates, and lipids as active pharmaceutical ingredient (s)" are unlikely to cause significant risk to the environment, due to the nature of these naturally occurring substances. Therefore, the ERA for such compounds can consist of a justification for not submitting ERA studies; however, no further details are provided on what merits such a justification (CHMP, 2006). According to the biopharmaceuticals definition applied in this paper, producers of non-modified biopharmaceuticals are therefore not obligated to perform ERA studies, but it should be noted that this only applies to naturally occurring active substances. The exclusion of naturally occurring substances avoids unnecessary calculations and testing, as no risk is assumed. Without mandatory testing, the risk of some compounds might proceed to go uninvestigated.

\subsubsection{Phase I of the EU ERA guideline}

Phase I of the ERA consists of two parts, namely, an estimation of predicted environmental concentration (PEC) and a hazard assessment for persistent, bioaccumulative and toxic (PBT) properties.

If calculations of the PEC in surface water $\left(\mathrm{PEC}_{\mathrm{SW}}\right)$ show that the trigger value of $0.01 \mu \mathrm{g} / \mathrm{L}$ is exceeded, the ERA should proceed to Phase II. If $\mathrm{PEC}_{\mathrm{SW}}$ is below the action limit of $0.01 \mu \mathrm{g} / \mathrm{L}$, and no other environmental risk is apparent, it is assumed that the medicinal product is unlikely to represent an environmental concern, if used as prescribed (CHMP, 2006; CHMP, 2018). Importantly, some pharmaceuticals can have adverse effects on the environment at concentrations below $0.01 \mu \mathrm{g} / \mathrm{L}$, according to the EU guideline (CHMP, 2006), and in such cases, the potential risk would go undetected in the current ERA procedures. CHMP (2006) does state that for potential endocrine disruptors and pharmaceuticals known to affect the reproduction of vertebrates and minor animals at concentrations below $0.01 \mu \mathrm{g} / \mathrm{L}$, the action limit may not be applicable. However, no further elaboration on how to test for this condition is conducted (CHMP, 2006).

In the second part of Phase I, the PBT assessment begins with screening based on a determination of the octanol/water partition coefficient $\left(\mathrm{K}_{\mathrm{ow}}\right)$. If the $\log \mathrm{K}_{\mathrm{ow}}$ is found to be above 4.5 , a definitive PBT assessment should be performed (CHMP, 2006; CHMP, 2018). The determination of the $\log \mathrm{K}_{\mathrm{ow}}$ value should be performed for all active ingredients regardless of whether the trigger value for the $\mathrm{PEC}_{\mathrm{Sw}}$ has been met. However, substances that have a natural origin are excluded for further studies and are not required to do the PBT assessment. This includes naturally occurring biopharmaceuticals (CHMP, 2006).

Studies have indicated that some drugs are potentially bioaccumulative in ecosystems, which is a concern, as adverse effects on biota can be induced as a result of the increased tissue concentration 
of the compound (Voulvoulis et al., 2016). To evaluate if a drug is potentially bioaccumulative, $\mathrm{K}_{\mathrm{ow}}$ is measured, which can be done by OECD tests 107, 117, and 123 (OECD, 1995; OECD, 2004; OECD, 2006a). In a study by Buchwald and Bodor (1998), $\mathrm{K}_{\mathrm{ow}}$ is evaluated for 188 nonzwitterionic peptides, using computerized models for available experimental data. Non-zwitterionic peptides have no electrically-charged functional groups and are thus outwardly neutral. Whether a peptide is non-zwitterionic depends on the $\mathrm{pH}$ and the isoelectric point of the specific groups of the amino acids within the peptide. $\mathrm{K}_{\mathrm{ow}}$ can therefore be argued to be highly pH-dependent, which is important to keep in mind when estimating $\mathrm{K}_{\mathrm{ow}}$ for biopharmaceuticals. At the same time, it was found that larger cyclic peptides have a higher log $K_{o w}$ value than first estimated, due to an increased number of hydrogen bonds. Predicting the number of such hydrogen bonds is difficult for larger molecules, but it does have a large impact on the solubility of the products (Buchwald and Bodor, 1998). Although OECD tests were originally designed for much smaller chemicals, it seems that measurements of $\mathrm{K}_{\mathrm{ow}}$ for biopharmaceuticals can be conducted to investigate the potential ability of non-zwitterionic peptides to bioaccumulate (Buchwald and Bodor, 1998). It is possible that the same method could be used to estimate the $\mathrm{K}_{\mathrm{ow}}$ for amino acid-based biopharmaceuticals in general; however, the literature on this topic is scarce. A general assumption is that the assessment of $\mathrm{K}_{\mathrm{ow}}$ is not relevant for biopharmaceuticals, as they are designed to show enhanced solubility in the water phase (Yasuda et al., 2012). As available literature is limited, it is recommended that at least one of the OECD tests $(107,117$, and 123) should be performed in Phase I for all active ingredients, independent of origin, in order to investigate the potential ability for biopharmaceutical bioaccumulation.

\subsubsection{Phase II of the EU ERA guideline}

Phase II of the ERA consists of several steps, including a determination of the physico-chemical properties, environmental fate, and ecotoxicological effects of the active substance, as well as a risk characterization (CHMP, 2006). In the current version of the EU guideline regarding medicinal product ERAs, water is considered the main compartment. In the draft version of the EU guideline, calculations are divided into six different compartments, of which surface water, sediment, and sewage treatment plants are mandatory (CHMP, 2018). Furthermore, the assessment of physico-chemical properties such as water solubility, octanol/water partitioning, and dissociation in water has become mandatory in Phase II in the draft version of the EU guideline regarding ERA of medicinal products that are not in the current guidelines (CHMP, 2018). According to the current guideline, as well as the draft version of the guideline, an estimated PEC/PNEC ratio below 1 signifies that further testing is not necessary, and it can be concluded that the test compound and/or its metabolites are unlikely to represent a risk to the aquatic environment (CHMP, 2006; CHMP, 2018). The PNEC value is estimated based on specific toxicity tests that typically follow the OECD guidelines. Conditions in ecotoxicological tests following OECD guidelines are controlled in order to ensure the mutual acceptance of data, and it is well-acknowledged that these tests do not relate to an environmentally genuine situation. ERA studies following the OECD guidelines are designed for soluble chemicals, and the test substance is expected to be soluble and stable in water during the test period, to ensure the reliability of the results (OECD, 2018). For manufacturing purposes, biopharmaceuticals are designed to be soluble in the water phase, so even though OECD test guidelines are designed for chemicals, this indicates that the tests are in general applicable to biopharmaceuticals.

No studies following the OECD guidelines were identified in the scientific literature for a range of physico-chemical properties, i.e. adsorption, aerobic and anaerobic transformation, early life stage toxicity tests, and reproduction tests according to OECD test guidelines 106, 308, 210, and 211, respectively (OECD, 1992b, 2000, 2002, 2012).

In terms of adsorption, a study conducted half a decade ago by Greaves and Wilson (1969) found that the adsorption of nucleic acids into clay minerals at a pH below five increases in line with a decreasing $\mathrm{pH}$. The tested nucleic acids are calf thymus DNA, higly polymerized DNA and RNA from yeast. At a pH above five, adsorption decreases to a minimum and is limited to the outer surface of the clay. The same adsorption pattern is expected for proteins. Furthermore, adsorption increases with the addition of electrolytes (Greaves and Wilson, 1969). If this applies to all soil types, it might be relevant to conduct an adsorption test on biopharmaceuticals, if the drug is distributed in areas with acidic soil. Additionally, in a more recent study, Hashizume (2015) concluded that clay minerals can adsorb RNA components, although the extent of this adsorption is limited. Biopharmaceuticals are designed to have negligible surface adsorption, in order to avoid aggregation, which correlates well with the findings by Greaves and Wilson (1969) and Hashizume (2015). Therefore, adsorption testing might not be relevant for biopharmaceuticals, and it can be discussed whether any test would be highly dependent on the biopharmaceutical's active ingredient.

OECD test 308 on aerobic and anaerobic transformation is a longterm assessment, and although it is the optimal method for examining environmental degradation rates and pathways, it is also expensive (Tyle, 2006). The degradation products of amino acid-based biopharmaceuticals are considered neutral when it comes to adverse effects (Mounho et al., 2008; Tang et al., 2004). OECD test 308 has been removed from the updated draft (CHMP, 2018). Instead, it is recommended to perform OECD 106, but it could be discussed whether the degradation pathway, which depends on the stability of the compound in a given situation, is more relevant than aerobic and anaerobic transformation. Therefore, we suggest that stability testing can be relevant regarding testing for transformation products and degradation pathways. This is in line with incorporating the biodegradability testing of biopharmaceuticals in the updated draft (CHMP, 2018).

3.3.2.1. Ready biodegradability. Testing for ready biodegradability is also part of Phase II. Ready biodegradability must be tested following the OECD 301 guideline, and the test must end within a 28-day period. The OECD 301 test guideline contains a description of six different methods that allow the screening of compounds for ready biodegradability in aerobic aqueous media (OECD, 1992a). In contrast to the current version of the guidance, stability testing has been included under Phase I in the updated draft version of the guidance, but this only applies to non-natural proteins and peptides (CHMP, 2018). Only one study of relevance was identified in the literature review, namely the study by Straub (2010). In this study, OECD 301 test guideline was followed to determine the ready biodegradability of eight biopharmaceuticals: one recombinant hormone, three recombinant monoclonal antibodies, one monoclonal antibody in development, a synthetic 36-amino-acid peptide, a synthetic 30-amino-acid peptide in development, and two PPTs covalently bound to a long-chain PEG (see Table 3). Six were found to be clearly readily biodegradable, whereas two polyethylene glycolated proteins were found to have increased stability. Therefore, we would recommend the inclusion of ready biodegradability testing in Phase I, which is also in line with the proposed draft of the guidance. However, according to Straub (2010), rapid biodegradation in sewage water and surface water takes place. Based on his study, he deduces that amino acid-based biopharmaceuticals are of no risk to the environment, in which case the categorical exclusion of such biopharmaceuticals seems well justified.

3.3.2.2. Growth inhibition. In Phase II, the growth inhibition test described in the OECD 201 test guideline is used to assess effects on the growth of freshwater cyanobacteria and/or microalgae (OECD, 2006b). Following OECD 201, Straub (2010) tested amino acid-based biopharmaceuticals, where slightly decreased growth compared to the control was observed in one instance (see Table 4). The moderate inhibition of growth of algae, in this case, can be caused by reduced light availability, due to turbidity in the algal medium and not by actual test 
Table 3

Summary of the findings reported by Straub (2010) on ready biodegradability of eight biopharmaceu-ticals following OECD $301 \mathrm{D}$ and F test guideline.

\begin{tabular}{|c|c|c|c|c|}
\hline Compound & Category & $\begin{array}{l}\text { Molar mass } \\
(\mathrm{g} / \mathrm{mol})\end{array}$ & $\begin{array}{l}\text { Endpoint } \\
\text { (BOD/ThODNO3 within } 10 \text { days) }\end{array}$ & Result \\
\hline Actemra ${ }^{\circledR}$, Tocilizumab & Protein & $\sim 150,000$ & $60 \%$ & Ready biodegradability \\
\hline Avastin $\circledast$, Bevacizumab & Protein & $\sim 150,000$ & $60 \%$ & Ready biodegradability \\
\hline MAbDevl & Protein & $\sim 150,000$ & $60 \%$ & Ready biodegradability \\
\hline Neorecormon $®$, Epoetin- $\beta$ & Protein & $\sim 37,000$ & $60 \%$ & Ready biodegradability \\
\hline Pegasys $®$, PEGylated interferon- $\alpha-2 a$ & Protein & $\sim 60,000$ & $60 \%$ & Poor biodegradability \\
\hline Mircera ${ }^{\circledR}$, PEGylated epoetin- $\beta$ & Protein & $\sim 60,000$ & $60 \%$ & Poor biodegradability \\
\hline Fuzeon $₫$, Enfuvirtide & Synthetic peptides & $\sim 4500$ & $60 \%$ & Ready biodegradability \\
\hline S30AAPPT & Synthetic peptides & $\sim 3300$ & $60 \%$ & Ready biodegradability \\
\hline
\end{tabular}

item toxicity. Additionally, an algal no observed effect concentration (NOEC) of approximately $80 \mathrm{mg}$ active pharmaceutical ingredient per $\mathrm{L}$ was found for the same biopharmaceutical. Furthermore, another test conducted on a different type of amino acid-based biopharmaceutical showed a low NOEC value over a 72-h time period regarding algal toxicity. However, the slope of the dose-response curve was found to be rather flat, with the percentage inhibition below $20 \%$ growth rate inhibition for all tested concentrations (Straub, 2010). Based on the fact that the real effects of amino acid-based biopharmaceuticals are still unknown, and very little information exists about the growth inhibition of other kinds of biopharmaceuticals, we recommend that growth inhibition tests are performed as part of Phase II.

\section{Table 4}

Summary of the findings reported by Straub (2010) of relevance for the ecotoxicology of biopharmaceu-ticals. API: Active pharmceutical ingredient; ND: Not determined; NOEC: No-observed-effect concentration.

\begin{tabular}{|c|c|c|c|c|c|}
\hline Compound & Category & $\begin{array}{l}\text { Molar mass } \\
(\mathrm{g} / \mathrm{mol})\end{array}$ & $\begin{array}{l}\text { OECD } \\
\text { guideline }\end{array}$ & Organism & $\begin{array}{l}\text { NOEC } \\
(\mathrm{mg} \mathrm{API} / \mathrm{I})\end{array}$ \\
\hline \multirow{4}{*}{$\begin{array}{l}\text { Actemra®, } \\
\text { Tocilizumab }\end{array}$} & \multirow{4}{*}{ Protein } & \multirow{4}{*}{$\sim 150,000$} & 201 & Algae & 100 \\
\hline & & & 202 & Daphnia & 100 \\
\hline & & & 203 & Fish & 100 \\
\hline & & & 301D; 301F & $\begin{array}{l}\text { Activated } \\
\text { slugde bacteria }\end{array}$ & 100 \\
\hline \multirow{4}{*}{$\begin{array}{l}\text { Avastin }{ }^{\circledR}, \\
\text { Bevacizumab }\end{array}$} & \multirow{4}{*}{ Protein } & \multirow{4}{*}{$\sim 150,000$} & 201 & Algae & $\sim 80$ \\
\hline & & & 202 & Daphnia & 100 \\
\hline & & & 203 & Fish & ND \\
\hline & & & 301D; 301F & $\begin{array}{l}\text { Activated } \\
\text { slugde bacteria }\end{array}$ & 100 \\
\hline \multirow{4}{*}{ MAbDevl } & \multirow{4}{*}{ Protein } & \multirow{4}{*}{$\sim 150,000$} & 201 & Algae & 100 \\
\hline & & & 202 & Daphnia & 100 \\
\hline & & & 203 & Fish & $<100$ \\
\hline & & & 301F; 301D & $\begin{array}{l}\text { Activated } \\
\text { slugde bacteria }\end{array}$ & 50 \\
\hline \multirow{4}{*}{$\begin{array}{l}\text { Neorecormon }{ }^{\circledR} \text {, } \\
\text { Epoetin- } \beta\end{array}$} & \multirow{4}{*}{ Protein } & \multirow{5}{*}{$\sim 37,000$} & 201 & Algae & 100 \\
\hline & & & 202 & Daphnia & 100 \\
\hline & & & 203 & Fish & ND \\
\hline & & & 301D; 301F & $\begin{array}{l}\text { Activated } \\
\text { slugde bacteria }\end{array}$ & 100 \\
\hline \multirow{4}{*}{$\begin{array}{l}\text { Pegasys }{ }^{\circledR}, \\
\text { PEGylated } \\
\text { interferon- } \alpha-2 \mathrm{a}\end{array}$} & \multirow{4}{*}{ Protein } & & 201 & Algae & ND \\
\hline & & \multirow{3}{*}{$\sim 60,000$} & 202 & Daphnia & 300 \\
\hline & & & 203 & Fish & 300 \\
\hline & & & 301D; 301F & $\begin{array}{l}\text { Activated } \\
\text { slugde bacteria }\end{array}$ & 800 \\
\hline \multirow{4}{*}{$\begin{array}{l}\text { Mircera }{ }, \\
\text { PEGylated } \\
\text { epoetin- } \beta\end{array}$} & \multirow{4}{*}{ Protein } & \multirow{4}{*}{$\sim 60,000$} & 201 & Algae & 200 \\
\hline & & & 202 & Daphnia & 200 \\
\hline & & & 203 & Fish & 200 \\
\hline & & & 301D; 301F & $\begin{array}{l}\text { Activated } \\
\text { slugde bacteria }\end{array}$ & 100 \\
\hline \multirow{4}{*}{$\begin{array}{l}\text { Fuzeon }{ }^{\circledR}, \\
\text { Enfuvirtide }\end{array}$} & \multirow{4}{*}{$\begin{array}{l}\text { Synthetic } \\
\text { peptides }\end{array}$} & \multirow{4}{*}{$\sim 4500$} & 201 & Algae & 100 \\
\hline & & & 202 & Daphnia & ND \\
\hline & & & 203 & Fish & ND \\
\hline & & & 301D; 301F & $\begin{array}{l}\text { Activated } \\
\text { slugde bacteria }\end{array}$ & 100 \\
\hline \multirow{4}{*}{ S30AAPPT } & \multirow{4}{*}{$\begin{array}{l}\text { Synthetic } \\
\text { peptides }\end{array}$} & \multirow{4}{*}{$\sim 3300$} & 201 & Algae & 6.3 \\
\hline & & & 202 & Daphnia & 200 \\
\hline & & & 203 & Fish & ND \\
\hline & & & 301D; 301F & $\begin{array}{l}\text { Activated } \\
\text { slugde bacteria }\end{array}$ & 25 \\
\hline
\end{tabular}

3.3.2.3. Respiratory inhibition test. According to the EU, the functioning of sewage treatment plants should be tested by conducting a respiratory inhibition test, following the OECD 209 test guideline. This test is used to assess the effects of a substance on microorganisms in activated sludge (OECD, 2010). As a part of the ready biodegradability test conducted by Straub (2010), and reviewed earlier in this paper, a toxicity control on activated sludge bacteria was performed for the eight investigated biopharmaceuticals. None of the test substances showed any inhibitory effect on the controls. Therefore, based on this study, the respiratory inhibition test might not be relevant for an ERA of proteinbased biopharmaceuticals. However, data in the field of respiratory inhibition tests are limited, and so it is inconclusive whether an OECD 209 test is relevant for the assessment of biopharmaceuticals.

\subsection{Stability}

The stability of biopharmaceuticals is essential, not only for their manufacturing and consumption, but also in terms of the environment. The stability and metabolism of a drug play a major role when use and consumption are the main routes for it ending up in the environment (European Commission, 2019). Degradation of a drug, just after the intended function, is preferred, in order to avoid any unintended action. Two major problems when developing biopharmaceuticals are low stability and a short half-life, leading to rapid degradation within the human body (Tang et al., 2004). According to Tang et al. (2004) the half-lives of 48 different biopharmaceuticals ranged from fewer than $5 \mathrm{~min}$ and up to 26 days. The majority, however, had half-lives of minutes and hours. Therefore, biopharmaceutical developers aim at increasing the stability of these drugs (Bye et al., 2014).

Conversely to the updated draft, the 2006 guideline does not mention or require the stability testing of biopharmaceuticals. As awareness has been raised in this area since 2006, this is likely to be the reason why CHMP (2018) has deemed it necessary to include stability testing. Further studies on the biostability are not required for every active substance in the updated draft guidance-only for structurally modified proteins and peptides using non-natural amino acids. If non-natural proteins or peptides are readily biodegradable or excreted in amounts of less than 10\%, then ERA studies can be put to a halt with no further analysis (CHMP, 2018).

Stability is determined by several factors. Temperature is considered an important factor, as it cause instabilities in biopharmaceuticals, which tend to be more stable at lower temperatures. Higher temperatures $\left(>25^{\circ} \mathrm{C}\right)$ can lead to increased denaturation and decreased stability. The average temperature, for instance in Denmark, from 1981 to 2010 was $8.3^{\circ} \mathrm{C}$ (Cappelen, 2018), and during the winter months, the temperature falls to near or below $0{ }^{\circ} \mathrm{C}$ (DMI, 2018), which is close to optimal storage temperatures for biopharmaceuticals. In addition, biopharmaceuticals are designed to remain stable for up to 2 years, under optimal conditions, which suggests that they may remain stable in, for instance, the Danish environment if released in their pristine form during or after use, or as waste. Considering temperature only, the assumption that biopharmaceuticals degrade in the environment is questionable. A study by Moresco et al. (2015), for example, found 
remaining rotavirus vaccine, a biopharmaceutical, after 240 days of incubation in non-chlorinated drinking water at $4{ }^{\circ} \mathrm{C}$. Another environmental factor that can affect the stability of biopharmaceuticals is $\mathrm{pH}$. Biopharmaceuticals are most stable at a neutral $\mathrm{pH}$, whereas an extreme $\mathrm{pH}$, in either direction, can cause degradation, loss of structure, or aggregation. A study by Mohamed et al. (2018) observed that one type of monoclonal antibody was able to remain relatively stable at a neutral $\mathrm{pH}$ during a four-week study. In the environment, $\mathrm{pH}$ will typically be in the neutral, slightly acidic range (NRCSS, 1993), thereby indicating that the $\mathrm{pH}$ in the environment is compatible with the optimum $\mathrm{pH}$ for biopharmaceuticals. This is problematic, as the fundamental assumption of biopharmaceuticals, in relation to regulation, is that they are rapidly degraded in the environment. In addition to ready biodegradability in the updated draft, stability testing is already performed as part of the pharmaceutical development stage, and we would therefore recommend this to be done with environmental considerations in mind.

\section{Conclusion}

A clear definition of biopharmaceuticals is the first step toward achieving an effective regulation. Through a thorough literature review, nine different definitions were identified. Our evaluation of existing definitions with regard to, for instance, whether the biological derivation, composition, and purpose were included established that the term "biopharmaceuticals" is used ambiguously, and variability in this regard is significant. Based on our evaluation of existing definitions, we recommend defining biopharmaceuticals as complex molecules that are derived from a biological source, with the purpose to diagnose, prevent, treat, or cure diseases or conditions of human beings. We furthermore recommend that biopharmaceuticals are categorized according to their biological structure and function: 1) amino acids, 2) nucleic acids, and 3) vaccines. According to the EU regulation and guidelines, biopharmaceuticals are excluded when performing ERA studies, due to the assumption that these products will not cause adverse environmental effects, due to their nature or natural origin. We have investigated and evaluated the pros and cons of the existing regulation and the ERA of biopharmaceuticals. The main challenge related to the current EU guideline is the lack of relevant scientific studies that follow the OECD tests as required in Phase II, and a categorical exclusion is not advantageous if the assessment is based entirely on the nature of a given biopharmaceutical product. We thus recommend the implementation of a case-by-case ERA of biopharmaceuticals so that all types and novel features can be systematically considered and evaluated, especially with regard to stability. Due to the lack of relevant studies, it is currently impossible to assess whether any potential hazardous effects may arise from using biopharmaceuticals. We therefore recommend that biopharmaceuticals must not excluded by default from further studies due to their natural origin, and we advise that the European Commission and EMA fund basic research into the fate, stability, and ecotoxicity of biopharmaceuticals.

\section{Declaration of competing interest}

The authors declare that they have no known competing financial interests or personal relationships that could have appeared to influence the work reported in this paper.

\section{References}

Bergquist, R., Lustigman, S., 2010. Control of important helminthic infections: vaccine development as part of the solution. Adv. Parasit. 73, 297-326.

Biotechnology Industry Organization (BIO), 2007. The difference with biologics: the scientific, legal, and regulatory challenges of any follow-on biologics scheme, 1-38. Available: https://www.bio.org/sites/default/files/files/WhitePaper.pdf.

Bowman, D.M., D’Silva, J., van Calster, G., 2010. Defining nanomaterials for the purpose of regulation within the European Union. Eur. J. Risk Regul. 1 (2), 115-122.
Buchwald, P., Bodor, N., 1998. Octanol-water partition of nonzwitterionic peptides: predictive power of a molecular size-based model. Proteins 30 (1), 86-99.

Bye, J.W., Platts, L., Falconer, R.J., 2014. Biopharmaceutical liquid formulation: a review of the science of protein stability and solubility in aqueous environments. Biotechnol. Lett. 36 (5), 869-875.

Cappelen, J., 2018. Temperaturen i Danmark. Danmarks Meteorologiske Institut Available: https://www.dmi.dk/klima/klimaet-frem-til-i-dag/danmark/temperatur/ [Accessed November 20th, 2020].

Committee for Medicinal Products for Human Use (CHMP), 2006. Guideline on the Environmental Risk Assessment of Medicinal Products for Human Use. Ref EMEA/CHMP/ SWP/4447/00 corr 2, European Medicines Agency. London: United Kingdom. Available:https://www.ema.europa.eu/en/documents/scientific-guideline/guideline-environmental-risk-assessment-medicinal-products-human-use-first-version_en.pdf [Accessed November 20th, 2020].

Committee for Medicinal Products for Human Use (CHMP), 2018. Guideline on the Environmental Risk Assessment of Medicinal Products for Human Use Draft. EMEA/ CHMP/SWP/4447/00 corr 2: 1-12. European Medicines Agency. London: United Kingdom. Available:https://www.ema.europa.eu/en/documents/scientific-guideline/ draft-guideline-environmental-risk-assessment-medicinal-products-human-use-revision-1_en.pdf [Accessed November 20th, 2020].

Conner, J., Wuchterl, D., Lopez, M., Minshall, B., Prusti, R., Boclair, D., Peterson, J., Allen, C., 2014. The biomanufacturing of biotechnology products. In: Shimasaki, C. (Ed.), Biotechnology Entrepreneurship. Academic Press, pp. 351-385.

Crommelin, D.J.A., Storm, G., Verrijk, R., De Leede, L., Jiskoot, W., Hennink, W.E., 2003. Shifting paradigms: biopharmaceuticals versus low molecular weight drugs. Int. J. Pharm. 266 (1-2), 3-16.

Danmarks Meteorologiske Institut (DMI), 2018. Klimanormaler. Danmarks Meteorologiske Institut. Available:https://www.dmi.dk/vejr/arkiver/normaler-ogekstremer/klimanormaler-dk/ [Accessed November 20th, 2020].

European Commission, 2014. What you need to know about biosimilar medical products. Available: https://www.medicinesforeurope.com/wp- content/uploads/2016/03/ biosimilars_report_en.pdf [Accessed November 20th, 2020].

European Commission, 2019. Communication from The Commission to The European Parliament, The Council and The European Economic and Social Committee European Union Strategic Approach to Pharmaceuticals in the Environment. COM (2019) 128 final. European Commission, Brussels. Available at:https://ec.europa.eu/ environment/water/water-dangersub/pdf/strategic_approach_pharmaceuticals_env. PDF [Accessed November 20th, 2020].

European Medicine Agency (EMA), 2015. Applying for EU marketing authorisation for medicinal products for human use, 1-6. Available at: http://www.ema.europa.eu/ docs/en_GB/document_library/Brochure/2011/03/WC500104233.pdf.

European Parliament, 2001. Directive 2001/83/EC of the European Parliament and of the Council. Off. J. Eur. Communities 311, 67-128 Available at:http://eur-lex.europa.eu/ LexUriServ/LexUriServ.do?uri=OJ:L:2001:311:0067:0128:en:PDF [Accessed November 20th, 2020].

European Parliament, 2004. Regulation (EC) no 726/2004 of the European Parliament and of the Council. Off. J. Eur. Communities 136, 1-70. https://ec.europa.eu/health/sites/ health/files/files/eudralex/vol-1/reg_2004_726/reg_2004_726_en.pdf [Accessed November 20th, 2020].

Foldvari, M., Chen, D.W., Nafissi, N., Calderon, D., Narsineni, L., Rafiee, A., 2016. Non-viral gene therapy: gains and challenges of non-invasive administration methods. J. Control. Release 240, 165-190.

Food and Drug Administration (FDA), 1998. Guidance for Industry Environmental Assessment of Human Drug and Biologics Applications. Rockville, MD. Available at:https:// www.fda.gov/media/70809/download [Accessed November 20th, 2020].

FDA, 2015. Drug, Not a Drug, or More? Avaialble:https://www.fda.gov/downloads/Drugs/ DevelopmentApprovalProcess/SmallBusinessAssistance/UCM462854.pdf. (Accessed 19 June 2018)

Greaves, M.P., Wilson, M.J., 1969. The adsorption of nucleic acids by montmorillonite. Soil Biol. Biochem. 1 (4), 317-323.

Hashizume, H., 2015. Adsorption of nucleic acid bases, ribose, and phosphate by some clay minerals. Life 5 (1), 637-650.

Ho, S.V., Mclaughlin, J.M., Cue, B.W., Dunn, P.J., 2010. Environmental considerations in biologics manufacturing. Green Chem. 12 (5), 755-766.

Kümmerer, K., 2009. The presence of pharmaceuticals in the environment due to human use - present knowledge and future challenges. J. Environ. Manag. 90 (8), 2354-2366.

Lybecker, K.M., 2016. The Biologics Revolution in the Production of Drugs. Fraser Institute, pp. 9-49.

Mohamed, H.E., Mohamed, A.A., Al-Ghobashy, M.A., Fathalla, F.A., Abbas, S.S., 2018. Stability assessment of antibody-drug conjugate trastuzumab emtansine in comparison to parent monoclonal antibody using orthogonal testing protocol. J. Pharm. Biomed. Anal. 150, 268-277.

Moresco, V., Damazo, N.A., Barardi, C.R.M., 2015. Rotavirus vaccine stability in the aquatic environment. J. Appl. Microbiol. 120 (2), 321-328.

Mounho, B.J., Bussiere, J.L., Weir, A.B., 2008. 6 Safety assessment of biotechnology-derived therapeutic drugs. In: Hammond, B.G. (Ed.), Food Safety of Proteins in Agricultural Biotechnology. CRC Press, Boca Raton, pp. 142-175.

Natural Resource Conservation Service Soils (NRCSS), 1993. Examination and description of soil profiles. Soil Survey Manual, U.S. Department of Agriculture Handbook Available:https://www.nrcs.usda.gov/wps/portal/nrcs/detail/soils/ref/?cid=nrcs142p2 054253 [Accessed November 20th, 2020].

NHS Pharmaceutical Research and Development Working Group, 2017. A standard protocol for deriving and assessment of stability part 2 - Aseptic preparations (biopharmaceuticals). NHS Pharmaceutical Quality Assurance Committee, Third edition, pp. 1-21. 
OECD, 1995. Test No. 107: Partition Coefficient (n-octanol/water): Shake Flask Method, OECD Guidelines for the Testing of Chemicals, Section 1. OECD Publishing, Paris https://doi.org/10.1787/9789264069626-en.

Ogbru, O., 2019. Biologics Definition, Side Effects, Uses, and List of Drug Names. MedicineNet.com. Available at: https://www.medicinenet.com/biologics_biologic drug_class/article.htm\#what_is_a_bio logic_drug_(biologics) [Accessed November 20th, 2020].

Organisation for Economic Co-operation and Development (OECD), 1992a. Test No. 301: Ready Biodegradability. Available:https:/www.oecd-ilibrary.org/environment/testno-301-ready-biodegradability_9789264070349-en [Accessed November 20th, 2020].

Organisation for Economic Co-operation and Development (OECD), 1992b. Test No. 210: Fish, Early-Life Stage Toxicity Test. Available at:http://www.oecd-ilibrary.org/environment/test-no-210-fish-early-life-stage-toxicity-test_9789264070103-en [Accessed November 20th, 2020].

Organisation for Economic Co-operation and Development (OECD), 2000. Test no. 106: adsorption - desorption using a batch equilibrium method. Available at:https:// www.oecd-ilibrary.org/environment/test-no-106-adsorption-desorption-using-abatch-equilibrium-method 9789264069602-en.

Organisation for Economic Co-operation and Development (OECD), 2002. Test no. 308 : aerobic and anaerobic transformation in aquatic sediment systems. Available at: https://www.oecd-ilibrary.org/environment/test-no-308-aerobic-and-anaerobictransformation-in-aquatic-sediment-systems_9789264070523-en.

Organisation for Economic Co-operation and Development (OECD), 2004. Test No. 117: Partition Coefficient (n-octanol/water), HPLC Method. Available at: https://www.oecdilibrary.org/docserver/9789264069824-en.pdf?expires=1569584410\&id=id\&accname $=$ guest $\&$ checksum $=2$ E1D0C32F1B771520D5BB45025322583 [Accessed November 20th, 2020].

Organisation for Economic Co-operation and Development (OECD), 2006a. Test No. 123: Partition Coefficient (1-Octanol/Water): Slow-Stirring Method. Available at:https:// www.oecd-ilibrary.org/docserver/9789264015845-en.pdf?expires $=15695847478 \mathrm{id}=$ id\&accname $=$ guest $\&$ checksum $=422503625363$ DBODECA76266AC1E0724 [Accessed November 20th, 2020].

Organisation for Economic Co-operation and Development (OECD), 2006b. Test No. 201: Alga, Growth Inhibition Test. Available at:http://www.oecd-ilibrary.org/environment/test-no-201-alga-growth-inhibition-test_9789264069923-en [Accessed: May 30th, 2018].
Organisation for Economic Co-operation and Development (OECD), 2010. Test No. 209: Activated Sludge, Respiration Inhibition Test. Available at:http://www.oecd-ilibrary. org/oecd/content/book/9789264070080-en [Accessed November 20th, 2020].

Organisation for Economic Co-operation and Development (OECD), 2012. Test No. 211 Daphnia Magna Reproduction Test. Available at:https://www.oecd-ilibrary.org/environment/test-no-205-avian-dietary-toxicity-test_9789264070004-en [Accessed November 20th, 2020].

Organisation for Economic Co-operation and Development (OECD), 2018. OECD Guidelines for the Testing of Chemicals. Available at:http://www.oecd.org/ chemicalsafety/testing/oecdguidelinesforthetestingofchemicals.htm [Accessed November 20th, 2020].

Parker, M., Li, Z., 2021. Chapter 22 - biotechnology and drugs. Remington (Twentythree Edition) The Science and Practice of Pharmacy, pp. 397-415 https://doi.org/ 10.1016/B978-0-12-820007-0.00022-2 [Accessed: March 3rd, 2021].

Public Health Service Act, 2010. 42 - The Public Health and Welfare Sec. 262 - Regulation of Biological Products.

Straub, J.O., 2010. Protein and peptide therapeuticals: an example of "benign by nature" active pharmaceutical ingredients. In: Kümmerer, K., Hempel, M. (Eds.), Green and Sustainable Pharmacy. Springer, Berlin Heidelberg, pp. 127-134.

Tang, L., Persky, A.M., Hochhaus, G., Meibohm, B., 2004. Pharmacokinetic aspects of biotechnology products. J. Pharm. Sci. 93 (9), 2184-2204.

The Public Health Service Act, 2011. Title 42 - The Public Health and Welfare Sec. 262 Regulation of Biological Products. Available at: https://www.govinfo.gov/content/ pkg/USCODE-2010-title42/pdf/USCODE-2010- title42-chap6A-subchapII-partFsubpart1-sec262.pdf [Accessed November 20th, 2020].

Tyle, H., 2006. Experiences of the PBT Group. The Danish Environmental Protection Agency, Copenhagen. Available:https://eng.mst.dk/chemicals/chemicals-in-products/assessment-of-chemicals/pbts-and-vpvbs/ [Accessed: June 5th, 2018].

Voulvoulis, N., Barceló, D., Verlicchi, P., 2016. Pharmaceutical residues in sewage treatment works and their fate in the receiving environment. In: Hester, R.E., Harrison, R.M. (Eds.), Issues in Environmental Science and Technology Pharmaceuticals in the Environment. The Royal Society of Chemistry, Cambridge, United Kingdom, pp. $120-179$.

Walsh, G., 2002. Biopharmaceuticals and biotechnology medicines: an issue of nomenclature. Eur. J. Pharm. Sci. 15 (2), 135-138.

Yasuda, S., Oshima, H., Kinoshita, M., 2012. Structural stability of proteins in aqueous and nonpolar environments. J. Chem. Phys. 137 (135103), 1-14. 